ADALAH : Buletin Hukum \&

Keadilan

Buletin Hukum \& Keadilan

@adalahuinjkt

\title{
Supremasi Ulama Dalam Pesta Demokrasi Pilkada
}

\author{
Ahmad Mukri Aji*
}

Ulama merupakan komponen penting dalam kehidupan masyarakat Indonesia. Ia merupakan gerbang penjaga moralitas bangsa. Kontribusi ulama tidak dapat dinafikkan, khususnya dalam melakukan perubahan akhlak negeri kearah yang lebih baik. Permasalahan yang dihadapi negeri ini harus merujuk kepada nasehat dan petuah ulama, karena ulama merupakan sumber inspirasi dalam memperkuat tatanan kehidupan berbangsa dan bernegara.

Ulama adalah pemuka agama atau pemimpin agama yang bertugas untuk mengayomi, membina dan membimbing umat Islam, baik dari sisi keagamaan maupun sosial kemasyarakatan. Makna sebenarnya ulama dalam bahasa Arab adalah ilmuwan atau peneliti, kemudian arti ulama tersebut berubah ketika diserap ke dalam Bahasa Indonesia, yang maknanya adalah sebagai orang yang ahli dalam ilmu agama Islam (Rahmat, 2017: 7).

Umara (birokrat) atau pejabat eksekutif adalah penguasa dan penentu kebijakan. Sedang ulama adalah seseorang yang menguasai dan mengajarkan ilmu agama. Antara ulama dan umara masingmasing akan dimintai pertanggungjawaban karena keduanya sama-sama memegang amanah berupa kekuasaan dan ilmu. Ulama berfungsi sebagai

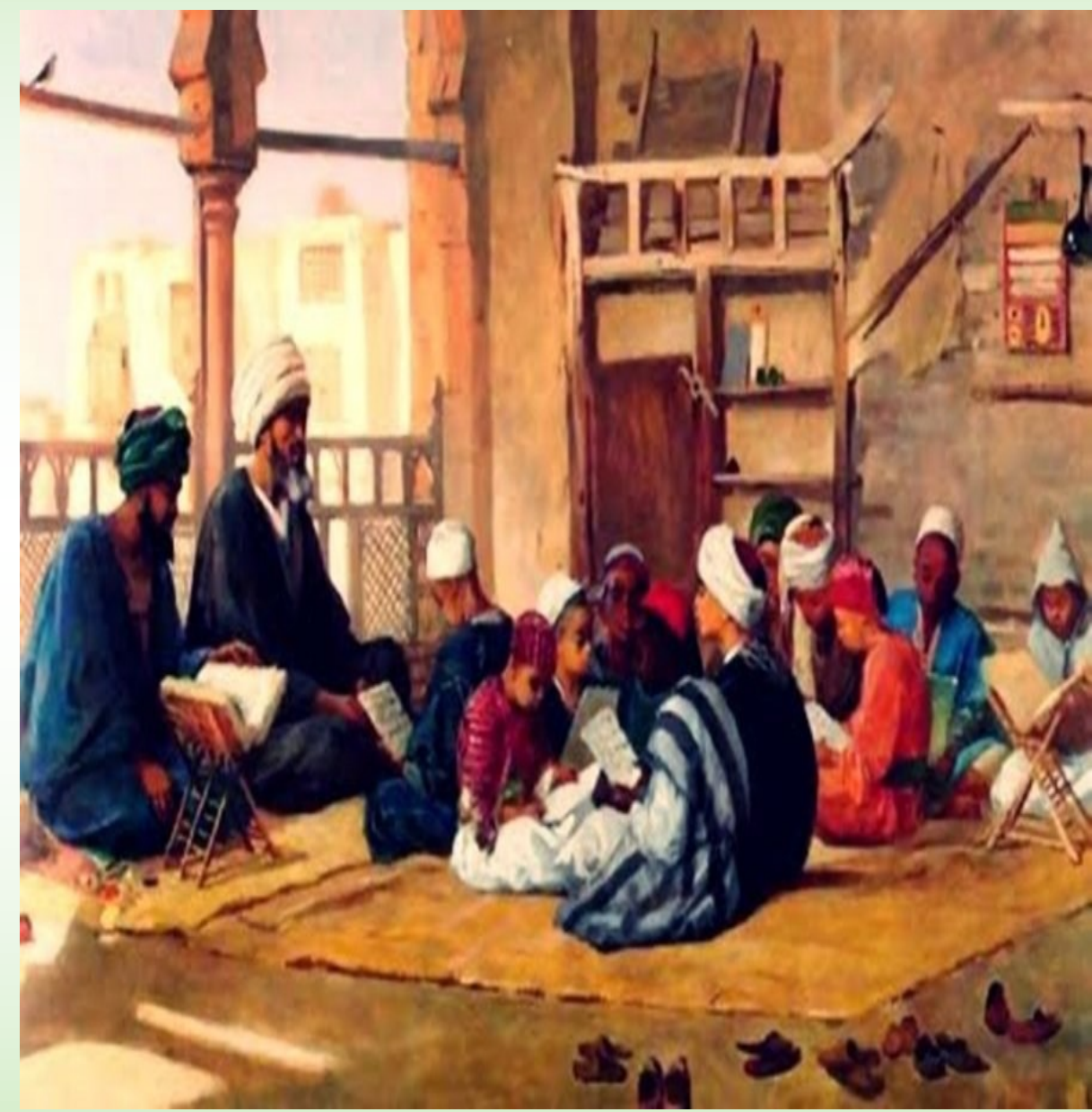

muaddib yang membimbing dan memberi motivasi, selain ulama berfungsi sebagai murabbi yang mendidik dan mengarahkan. Selain itu ulama berfungsi sebagai mujahid yang bertugas memperjuangkan kemaslahatan agama dan umat, terutama perbaikan taraf hidup dan membela umat yang terhimpit dari kesulitan.

Dalam perhelatan Pilkada Serentak 2019 pun, suara ulama juga mesti dapat dijadikan sebagai pertimbangan. Walau pilkada sarat dengan kepentingan, tetapi kepentingan ulama tidak akan jauh dari kepentingan umat dan Islam. Karenanya, suara ulama harus menyatu dalam kebersamaan untuk menyuarakan kebenaran serta kejayaan Islam dan muslimin, $l i$ izzatil Islam wa muslimiin. Ulama harus mampu memilah calon pemimpin yang pro keumatan, keberpihakan kepada agama Islam, 
dan mampu bersinergi dengan ulama. Selain syarat $k a f a ' a h$ dan kepemimpinan politik harus tetap dinilai.

Sosok ulama bukanlah orang biasa, ia bahkan telah menjadi makhluk langka yang nyaris hilang. Walau banyak yang mengaku ulama, tetapi aspek keilmuan yang menjadi syarat identitas ulama sering tidak terpenuhi. Sehingga berakibat pada orientasi yang salah karena minimnya keilmuan Islam dalam diri sosok yang mengaku ulama tadi. Atau boleh jadi dari segi kapabilitas ilmu sudah layak, tapi integritas dirinya belum tepat dianggap sebagai ulama. Atau mungkin, kapabilitas dan integritasnya sudah cukup baik, tapi penampilannya yang menurut masyarakat awam belum layak untuk menjadi ulama. Sebab masyarakat melihat sosok ulama adalah mereka yang identik dengan kopiah, sarung dan sorban. Bila demikian, ulama adalah figur yang di dalamnya terintegrasi dalam dirinya tiga komponen utama. Pertama, kapasitas ilmu; kedua, integritas dirinya; dan ketiga, penampilan fisiknya. Tiga hal yang disebutkan ini sifatnya hanyalah standar minimal yang harus dipenuhi. Sebab boleh jadi, dalam wilayah tertentu ada tambahan syarat seperti bahwa ulama itu harus memiliki santri, jamaah dan pesantren.

Dalam kontekstasi Pilkada seperti dalam hal pemilihan Bupati Bogor Jawa Barat, ulama bersinergi dalam satu kesatuan. Tidak bermain politik praktis, tetapi politik substansial. Artinya hanya merestui kepemimpinan politik yang berpihak kepada kejayaan Islam bukan hanya kejayaan partai politiknya belaka. Bila hal ini dilakukan, umat akan mendengar dan patuh kepada ulama. Sehingga dipastikan kepemimpinan politik yang diusung dan direstui ulama dapat lahir sebagai pemenang. Pemimpin yang terpilih pun akan selalu mengindahkan ulama sebagai panutan. Ada kebersamaan nantinya antara ulama dan umara. Ulama yang menasehati umara, dan umara yang mendengarkan nasehat ulama.

Melihat kentalnya kehidupan agama di kalangan masyarakat di Kabupaten Bogor, baik di daerah perkotaan, pedalaman, maupun pesisir sudah dapat dipastikan tidak terlepas dari peran penting seorang elit agama atau ulama. Orang Jawa mengatakan ning endi wae kyai mlaku wong cilik tinggal nunut, yang artinya kemanapun seorang ulama melangkah, maka masyarakat akan mengikutinya (Riyanto, 2015: 427)

Miris memang bila suatu masyarakat tidak lagi mengindahkan suara ulama. Ulama seolah tidak lagi memiliki supremasi apapun. Padahal ulama adalah warasatul anbiya', pewaris para nabi, yang memiliki kominten dan keteguhan untuk menegakkan ketauhidan dan kebenaran, bukan kebatilan apalagi arogansi politik yang semu belaka.[]

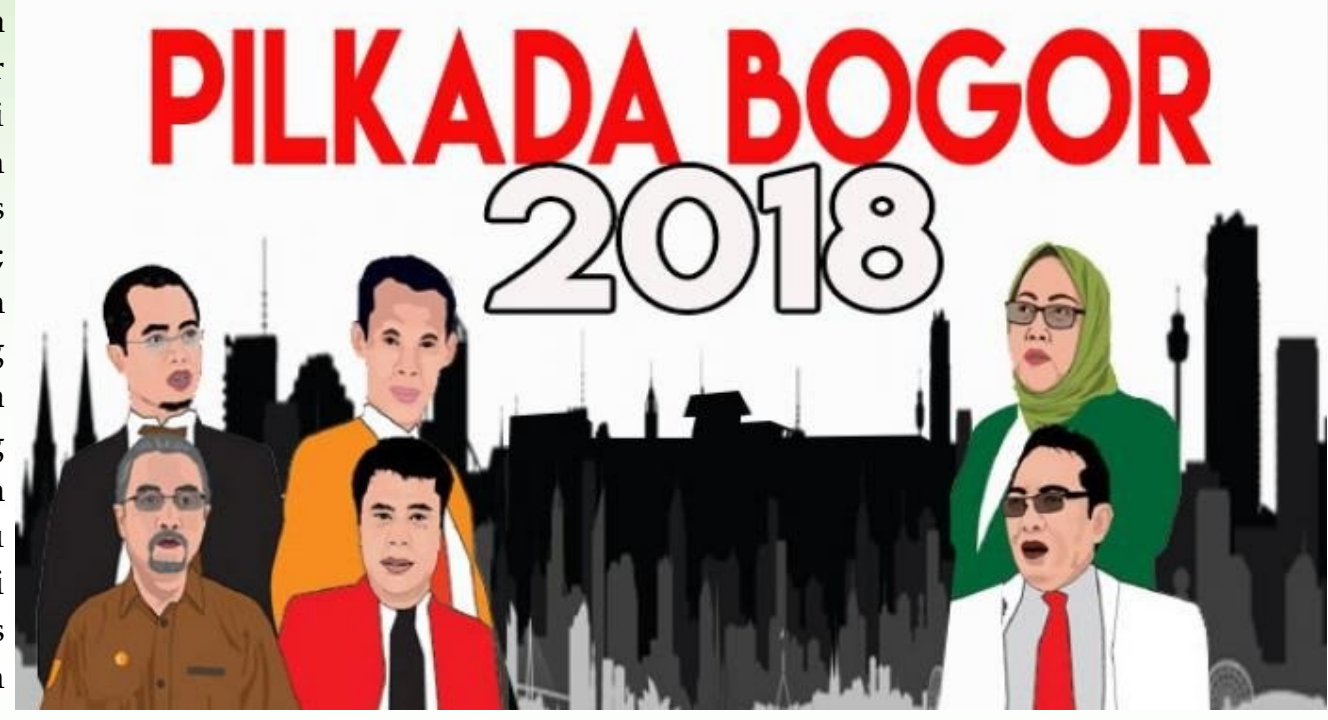

Pustaka Acuan:

*Penulis adalah Ketua Umum Majelis Ulama Indonesia (MUI) Kabupaten Bogor, sekaligus Kiai Pengasuh Pondok Pesantren Darun-Na'im Yapia Parung Bogor Jawa Barat.

Riyanto, "Peran Ulama dalam Meningkatkan Kesadaran pemilih pada pemilu presiden dan wakil presiden RI tahun 2014 di Kabupaten Demak," ADDIN, Vol. 9, No. 2, Agustus 2015.

Rahmat, Bai, "Elite Penentu Dalam Politik Lokal (Studi Kasus Peran Ulama Terhadap Pemenangan Sofyan Caleg Dapil I Kecamatan Bantan Kabupaten Bengkalis Tahun 2014)," dalam Jurnal JOM FISIP Vol. 4 No. 2 - Oktober 2017.

'Adalah; Buletin Hukum dan Keadilan merupakan berkala ilmiah yang diterbitkan oleh Pusat Studi Konstitusi dan Legislasi Nasional (POSKO-LEGNAS), Fakultas Syariah dan Hukum UIN Syarif Hidayatullah Jakarta.

Penasehat: Prof. Dr. H. Abdul Ghani Abdullah, SH., Prof. Dr. H. A Salman Maggalatung, SH., MH. Pemimpin Redaktur: Indra Rahmatullah, Tim Redaktur: Nur Rohim Yunus, Fathuddin, Mara Sutan Rambe, Muhammad Ishar Helmi, Erwin Hikmatiar. Penyunting: Latipah, Siti Nurhalimah. Setting \& Layout: Siti Romlah 